\title{
USO DE LAS TECNOLOGÍAS DE LA INFORMACIÓN Y LA COMUNICACIÓN EN PSICOLOGÍA CLÍNICA
}

\author{
Cristina Botella y Juana Bretón-LóPez \\ Universidad Jaime I, Castellón (España)
}

Este número monográfico pretende mostrar algunos de los avances que se han producido en el uso de las tecnologías de la información y la comunicación (TIC) en el marco de la psicología clínica $y$, fundamentalmente, por lo que respecta a los tratamientos psicológicos. El objetivo que se pretende es ejemplificar dichas posibilidades en una serie de trabajos que ayuden a comprender a los clínicos el potencial que las TICs tienen para este campo y a los investigadores posibles nuevas rutas de exploración. Resulta imposible analizar todos los desarrollos que se han producido en los últimos 25 años, por ello, nos limitamos a algunas de las tecnologías más utilizadas. Los artículos incluidos en este número monográfico abordan el uso de la realidad virtual, las intervenciones basadas en Internet, las aplicaciones móviles, las redes sociales seguras, y los juegos serios en la investigación y el tratamiento de distintos trastornos psicológicos.

La realidad virtual (RV) es una tecnología que permite crear ambientes tridimensionales generados por ordenador. El elemento esencial de la RV es que simula la realidad haciendo que el usuario experimente la sensación de "estar" en esos ambientes tridimensionales, así como permitirle interactuar con los objetos virtuales. La RV se ha convertido en una herramienta terapéutica valiosa ya que ofrece a los usuarios (pacientes y terapeutas) la posibilidad única de contar con un ambiente seguro y controlado que facilita la aplicación de diferentes componentes de un tratamiento psicológico (Botella, García-Palacios, Quero, Baños, y Bretón, 2006). La $\mathrm{RV}$ ha demostrado ser eficaz en el tratamiento de distintos trastornos psicológicos $\mathrm{y}$, en estos momentos, ya existen datos acerca de la eficacia de estos procedimientos, tanto derivados de estudios controlados, como de estudios de re- visión y de meta-análisis (David, Matu y David, 2013; Opris, Pintea, García-Palacios, Botella, Szamosközi, y David, 2012; Powers y Emmelkamp, 2008; McCann, Armstrong, Skopp, Edwards-Stewart, Smolenski, June, Metzger-Abamukong, y Reger, 2014; Turner y Casey, 2014). En suma, puede decirse que la RV es una valiosa herramienta que ayuda a llevar a cabo la terapia, ofreciendo un ambiente protegido en el que la persona puede afrontar sus problemas de forma gradual y controlada.

En este número monográfico, se presenta un trabajo de Agliaro-López, Ferrer-García, Pla-Sanjuanelo y Gutiérrez-Maldonado, en el que se aplican técnicas de exposición a determinadas señales utilizando la RV, para provocar craving por comida. Se utilizan dispositivos de visualización no inmersivos y una serie de entornos virtuales para exponer a participantes sanos a distintos alimentos. Los autores concluyen que los procedimientos basados en la exposición a comida en entornos de RV son capaces de provocar craving por comida, lo cual puede suponer la facilitación del tratamiento basado en la exposición a señales relacionadas con la comida en pacientes con trastornos alimentarios.

Botella, Bretón-López, Serrano, García-Palacios, Quero y Baños presentan un trabajo en el que se utiliza un software de RV para el tratamiento de la fobia a volar. El software de RV está diseñado para llevar a cabo la exposición a los estímulos relacionados con el hecho de volar en pacientes diagnosticados con este problema. En el trabajo se somete a prueba la posible utilidad percibida acerca de la utilización o no de la reestructuración cognitiva junto con la exposición. Para ello, los participantes se asignaron a dos condiciones experimentales: tratamiento de exposición por medio del software 
“exposure treatment" de RV (VRET), o VRET más reestructuración cognitiva (VRET $+\mathrm{CR}$ ). Una vez aplicadas estas dos modalidades de tratamiento, se analizaron las opiniones y preferencias de los pacientes con respecto a las dos opciones de tratamiento. Los resultados muestran que todos los participantes consideran que ambas modalidades de tratamiento son lógicas y las encuentran útiles para ayudarles a superar el problema, pero prefieren la combinación de VRET + CR, frente a sólo VRET. Los autores subrayan la importancia de tomar en consideración las preferencias de los pacientes en la toma de decisiones con respecto al tratamiento, y sugieren que tener en cuenta estas preferencias podría tener un efecto en la reducción de las tasas de rechazo/abandono existentes en el tratamiento de las fobias específicas.

Al igual que sucede en cualquier protocolo de tratamiento, resulta importante tomar en consideración los contextos culturales en los que se van a aplicar los sistemas de RV. Este es el objetivo del trabajo llevado a cabo por Cárdenas, Botella, Baños, Quero, Durán y de la Rosa. Estos autores toman como punto de partida una serie de softwares de RV, desarrollados originalmente por el grupo de Botella, para el tratamiento del miedo a volar, el miedo a hablar en público, y la agorafobia, que ya han demostrado su eficacia en una muestra de población española. A partir de estos sistemas de RV, llevan a cabo adaptaciones tomando en consideración, las diferencias contextuales de los entornos físicos (p.ej., aspectos característicos de México D.F.) y las diferencias respecto al lenguaje. Una vez hecha la adaptación, realizan una validación transcultural en muestras de pacientes de población mexicana que sufren estos problemas. Los resultados indican que las intervenciones resultaron eficaces y los autores subrayan la conveniencia de prestar atención a todos estos aspectos relacionados con la validez externa.

En muchos trabajos en este ámbito se han subrayado los aspectos positivos de la utilización de RV para mejorar/apoyar la aplicación de los tratamientos psicológicos y, básicamente, la técnica de exposición. Sin embargo, han recibido menos atención los posibles efectos secundarios negativos de la RV. Este es precisa- mente el objetivo que presentan Quintana, Bouchard, Serrano y Cárdenas-López. Estos autores describen con cierto detalle los efectos secundarios negativos que a veces se producen al estar inmersos en un escenario de RV, efectos también conocidos como "cybersickness". El estudio se lleva a cabo utilizando exposición por medio de RV en pacientes diagnosticadas con trastornos de ansiedad. La conclusión del trabajo es que, afortunadamente, estos efectos tienen una prevalencia relativamente baja $\mathrm{y}$, a veces, pueden confundirse con los síntomas de la ansiedad provocados por los entornos de RV. Por otra parte, los autores analizan y cuestionan la validez de constructo del Simulator Sickness Questionnaire, el instrumento más utilizado para evaluar cybersickness y ofrecen sugerencias que podrían ayudar a superar algunos de los efectos secundarios negativos asociados con la inmersión en la RV. Sin duda, este aspecto tiene una gran importancia y forma parte de las cautelas éticas que siempre deberían considerarse desde una perspectiva general, en el ámbito de los tratamientos $\mathrm{y}$, de forma más específica, por todo lo que pueda estar implicado en el uso de las TICs (Botella, García-Palacios, Baños y Quero, 2009).

Serino, Cipresso, Gaggioli, Pallavicini, Cipresso, Campanaro y Riva centran su atención en el potencial que pueden tener las TICs para mejorar el bienestar y la calidad de vida. Estos autores describen una aplicación a la que llaman Positive Technology desarrollada para ser utilizada en los teléfonos inteligentes y las tablets. Se trata de la primera aplicación diseñada específicamente para el auto-manejo del estrés. Positive Technology además, utiliza una serie de biosensores e incluye ejercicios de biofeedback y relajación. En el trabajo se describe cómo se somete a prueba esta aplicación y los resultados muestran que su uso consigue una disminución significativa del estrés psicológico percibido y de la ansiedad; y un aumento en la calidad de la experiencia. Los autores discuten el enorme potencial de estas aplicaciones diseñadas para ser utilizadas en dispositivos móviles, para reducir el estrés psicológico y para ayudar en el manejo de muchos otros problemas. Sin duda, en los próximos años vamos a ser testigos del surgimiento de numerosas aplicaciones en el 
ámbito de la salud y el reto es someterlas a prueba para delimitar su eficacia, en qué contextos y para qué problemas. A este respecto cabe señalar que, desde esta perspectiva, la detección del estado emocional conlleva el análisis de una serie de variables de diferente naturaleza, tales como parámetros contextuales, relaciones sociales, variables fisiológicas, expresión facial, etc. Las últimas tendencias apuntan a la utilización de complejas técnicas de clasificación y análisis multidimensional de datos para poder detectar estados emocionales con cierta fiabilidad. Dentro de los sistemas de sensores, cobran especial relevancia el uso de los smartphones. Estos dispositivos son especialmente interesantes para la investigación en psicología por ser ubicuos, no obstrusivos, discretos, multisensoriales, computacionalmente potentes y accesibles remotamente. Cabe recordar aquí el Smartphone Psychology Manifesto de Miller (2012) y su predicción acerca de la revolución que va a suponer en el ámbito de la Psicología. Sin duda, los smartphones presentan un enorme potencial para la captura objetiva, precisa, continua y ecológicamente válida de datos de comportamiento de miles de usuarios en su entorno real de interacción sin necesidad de transportarlos a ningún laboratorio.

Otro desarrollo tecnológico basado en TICs que ha tenido un enorme crecimiento en los últimos años es la utilización de Internet para aplicar los tratamientos psicológicos basados en la evidencia. Se trata de programas muy estructurados que guían al paciente paso a paso (con mayor o menor apoyo por parte del clínico) a lo largo de todo el proceso de tratamiento. Las revisiones sistemáticas muestran que los tratamientos a través de internet son eficaces (Andrews et al., 2010; Cuijpers, et al., 2010, 2011; Spek et al., 2007; Richard y Richardson, 2012). Los meta-análisis muestran que se obtienen tamaños del efecto mayores que las condiciones de control y son tan eficaces como el tratamiento tradicional cara a cara. En resumen, existe amplia evidencia acerca de la eficacia de los estos tratamientos. Dos artículos de este número monográfico se centran en este tema. En primer lugar, Andersson, Bergman Nordgren, Buhrman y Carlbring llevan a cabo una revisión de los estudios controlados más recientes sobre la terapia cognitivo-conductual para la depresión aplicada por medio de internet (TCCI). Los resultados de la revisión ponen de manifiesto que la TCCI para la depresión tiene un excelente apoyo empírico. Los autores analizan una serie de aspectos relevantes en este ámbito, tales como el creciente número de estudios controlados que se han llevado a cabo en los últimos años para muchos otros trastornos (por ejemplo, pánico, agorafobia, fobia social, etc.); el uso de otros tratamientos distintos a los enfoques cognitivo-comportamentales (por ejemplo, la actividad física o la terapia psicodinámica aplicada por medio de internet); la posibilidad de someter a prueba intervenciones transdiagnósticas y personalizadas para cada paciente; $y$ el papel de la ayuda proporcionada por los clínicos a los pacientes durante todo el proceso de tratamiento. En otro trabajo también centrado en la utilización de internet, Cuijpers y Riper ofrecen una visión general de la investigación sobre las intervenciones psicoterapéuticas aplicadas por medio internet y analizan temas centrales relacionados con estos avances, tales como los datos existentes hasta el momento acerca de la eficacia de estos tratamientos; si las intervenciones basadas en Internet y otras intervenciones guiadas de auto-ayuda son tan eficaces como las terapias cara a cara; si este tipo de intervenciones se deben centrar únicamente en problemas de gravedad leve o moderada; y el papel y la cantidad de apoyo proporcionado por el clínico a los pacientes durante el tratamiento. Los autores también analizan la posible implementación de estas intervenciones, tanto a nivel de asistencia psicológica llevada a cabo en los sistemas nacionales de salud como a nivel privado. Defienden la conveniencia de llevar estrategias de intervención innovadoras que ayuden a resolver los notables problemas que existen en el ámbito de la salud mental: desde la integración de forma rutinaria de estas intervenciones basadas en internet en atención primaria y en atención especializada en salud mental, el desarrollo de intervenciones específicas para la prevención de recaídas y el mantenimiento de los logros de la terapia. Concluyen que este tipo de intervenciones pueden ayudar a paliar la carga derivada de los proble- 
mas de salud mental, tanto en los países industrializados como en los países emergentes o países del tercer mundo.

La aplicación de las TICs en las intervenciones psicológicas diseñadas para los niños y adolescentes es el foco de dos artículos de este monográfico. Bornas, Llabrés, Balle, Torre-Luque y Fiol-Veny exploran un ámbito enormemente innovador, esto es, las posibilidades que puede tener la utilización de una red social segura para la recogida de datos muchos más precisos sobre la sintomatología ansiosa en adolescentes, que lo que permiten los sistemas tradicionales. Se presentan dos estudios, en el Estudio 1 se describe la estructura y funcionamiento de la red social segura XS2, además de proporcionarse resultados sobre el acceso y uso de los participantes. En el Estudio 2 se presentan los resultados de las variaciones del estado emocional cotidiano y el uso de estrategias de regulación emocional desadaptativas durante un período de exámenes, así como la influencia de factores de riesgo sobre ellas. Los autores analizan algunos de los beneficios que una red de este tipo puede aportar al estudio de la evolución de los problemas de ansiedad en los adolescentes y, asimismo, contemplan los notables desafíos que suponen contactar y motivar a los participantes a utilizar la red. Por otra parte, Fleming, Cheek, Merry, Thabrew, Bridgman, Stasiak, Shepherd, Perry y Hetrick exploran la potencial contribución de los juegos serios ("serious games") en las intervenciones centradas en el ámbito de la salud mental. En el trabajo se centran en las intervenciones basadas en juegos serios para ayudar en el tratamiento de la depresión. Estos autores analizan las ventajas y/o los beneficios que estas intervenciones pueden tener para los niños, adolescentes y jóvenes que sufran de depresión y subrayan también las deficiencias de la investigación llevada a cabo en este campo hasta el momento. Los datos que aporta su revisión ponen de manifiesto que los juegos serios pueden ser estrategias muy útiles para ayudar en el tratamiento de la depresión en estas poblaciones, pero por el momento la literatura existente que lo avale es todavía limitada.

Dado el notable desarrollo que se ha producido en este ámbito de investigación resulta imposible reflejar la situación actual, no obstante este número monográfico trata de esbozar las posibilidades que permiten las TICs para la Psicología Clínica. Esperamos que estos ejemplos sirvan para animar a los profesionales de la salud mental a incluir estas nuevas herramientas basadas en TICs en su práctica clínica cotidiana. De la misma forma, también esperamos que estos ejemplos ayuden a los investigadores interesados en hacer avanzar el campo a explorar las posibilidades de las TICs para mejorar y diseminar las intervenciones psicológicas basadas en la evidencia.

\section{THE USE OF INFORMATION AND COMMUNICATION TECHNOLOGIES IN CLINICAL PSYCHOLOGY}

This special issue aims to show some of the advances that have occurred in the use of information and communication technology (ICT) within the framework of clinical psychology and, fundamentally, with regard to psychological treatments. The objective sought is to exemplify these possibilities in a series of works that, on the one hand, will help clinicians understand the potential that ICTs have for this field, and, on the other hand, will show researchers new possible routes to explore. It would be impossible to analyze all the developments that have occurred over the last 25 years, therefore we will limit the discussion to some of the more commonly used technologies. The articles included in this issue address the use of virtual reality, internet-based interventions, mobile applications, secure social networks, and serious games in the research and treatment of psychological disorders.

Virtual reality (VR) is a technology that allows creating three-dimensional computer-generated environments. The essential element of VR is that it simulates reality, making the user 
experience the feeling of "being" in these three-dimensional environments, and enabling interaction with virtual objects. VR has become a valuable therapeutic tool, offering the users (patients and therapists) the unique possibility of a safe and controlled environment that facilitates the implementation of different components of a psychological treatment (Botella, García-Palacios, Quero, Baños, \& Bretón, 2006). VR has proven effective in the treatment of various psychological disorders. Up to now, data about the effectiveness of these procedures has been derived from controlled studies, reviews, and meta-analyses (David, Matu, \& David, 2013; Opris, Pintea, García-Palacios, Botella, Szamosközi, \& David, 2012; Powers \& Emmelkamp, 2008; McCann et al., 2014; Turner \& Casey, 2014). In summary, we can say that VR is a valuable tool that helps carry out therapy, offering a protected environment in which the person can deal with problems in a gradual and controlled manner.

In this special issue is presented a work from Agliaro-López, Ferrer-García, Pla-Sanjuanelo and Gutiérrez-Maldonado, in which cue exposure techniques are applied using VR in order to elicit food craving. Through non-immersive devices and virtual environments, healthy participants are exposed to different foods. The authors conclude that procedures based on food exposure in VR environments are able to elicit food craving, which can facilitate cue-exposure-based therapy for patients with eating disorders.

Botella, Bretón-López, Serrano, García-Palacios, Quero, and Baños present a work in which they use VR software for the treatment of fear of flying. The VR software is designed to expose patients diagnosed with this disorder to flying-related stimuli. The work tests the perceived usefulness of cognitive restructuring together with exposure. In doing so, the participants were assigned to two experimental conditions: virtual reality exposure treatment (VRET) by itself and VRET plus cognitive restructuring $(\mathrm{VRET}+\mathrm{CR})$. Once these two treatment modalities were applied, patients' opinions and preferences regarding the two choices of treatment were analyzed. The results show that all participants considered both treatment mo- dalities to have a logical purpose and to be useful, but they preferred VRET+CR over VRET only. The authors underline the importance of patients' preferences in making decisions about treatment, and suggest that taking these preferences into account could have an effect in reducing the dropout rates found in the treatment for specific phobias.

Like any other treatment protocol, it is important to consider the cultural context in which the VR systems are applied. This is the aim of the work conducted by Cárdenas, Botella, Baños, Quero, Durán, and De la Rosa. The authors take as their starting point a VR software series, originally developed by Botella's research group, for the treatment of fear of flying, fear of public speaking, and agoraphobia, which had proven effective in a Spanish population sample. They made adaptations to the software, taking into consideration contextual differences of the physical environments (e.g., characteristic features of Mexico City) and language-related differences. Once the adaptation was realized, they conducted a transcultural validation in patient samples from the Mexican population suffering from these problems. The results indicate that the interventions are effective, and the authors underline the importance of paying attention to all aspects related to external validity.

Many works in this field have emphasized the positive aspects of using VR to enhance/ support the implementation of psychological treatments and exposure techniques. However, the possible negative side effects of VR have received less attention. This is the aim of the work presented by Quintana, Bouchard, Serrano, and Cárdenas-López. They describe in detail the negative side effects that sometimes occur while immersed in a VR environment, also known as "cybersickness." The study is carried out using VR exposure in patients diagnosed with anxiety disorders. The conclusion of the study is that fortunately, these effects have a relatively low prevalence and sometimes might be confounded with anxiety-induced symptoms elicited by VR environments. Moreover, they analyze and question the construct validity of the Simulator Sickness Questionnaire (SSQ), the most widely used instrument to assess cy- 
bersickness, and offer suggestions that could help overcome some of the negative side effects associated with VR immersion. Certainly, this aspect is of great importance and forms part of the ethical precautions that should always be considered from a general perspective in the field of treatment and, more specifically, in the field of ICTs (Botella, García-Palacios, Baños, \& Quero, 2009).

Serino, Cipresso, Gaggioli, Pallavicini, Cipresso, Campanaro and Riva focus on the potential for improving wellbeing and quality of life through the use of ICTs. They describe a smartphone and tablet application called Positive Technology, the first of its kind designed for the self-management of psychological stress. Moreover, Positive uses wearable sensors and includes biofeedback and relaxation exercises. In this work the authors describe the process of testing this application and the results show significant decreases of the perceived psychological stress and anxiety, and an increase in the quality of the personal experience after using the application. The authors discuss the potential of these mobile applications designed to reduce psychological stress and to aid in the management of many other problems. Certainly in the coming years we will witness the emergence of numerous applications in the field of health. The challenge is testing them to determine their efficacy in particular contexts and for particular problems. In this respect, it should be noted that the detection of emotional mood involves the analysis of a number of variables of different nature, such as contextual parameters, social relationships, physiological variables, facial expressions, etc. Recent trends suggest the use of complex classification techniques and multidimensional data analysis to detect emotional states with a certain degree of reliability. Within sensor systems, the use of smartphones is particularly relevant. These devices are particularly interesting for research in psychology, as they are ubiquitous, unobtrusive, discrete, multisensory, computationally powerful, and accessible remotely. Miller's Smartphone Psychology Manifesto (2012) and his prediction of the revolution that smartphones will bring to the field of psychology should be noted here. Undoubtedly, smartphones have huge a potential for capturing objective, accurate, continuous and ecologically valid behavioral data of thousands of users in their real environment without needing to bring them into the laboratory.

Another technological development based on ICT that has grown tremendously in recent years is the use of the internet to apply psychological treatments based on evidence. These are very structured programs that guide the patient step by step (with varying degrees of support from a clinician) throughout the treatment process. Systematic reviews show that treatments over the internet are effective (Andrews et al., 2010; Cuijpers et al., 2010, 2011; Spek et al., 2007; Richard \& Richardson, 2012). The meta-analyses show that the effect sizes are greater for internet-delivered interventions than for control conditions, and moreover that these interventions are as effective as traditional faceto-face treatment. In short, there is ample evidence about the efficacy of these treatments. Two articles of this special issue are dedicated to the research conducted on internet-based psychological interventions. In the first place, Andersson, Bergman Nordgren, Buhrman and Carlbring review the most recent controlled studies on guided internet-delivered cognitive behaviour therapy (ICBT) for depression. The results of this review show that guided ICBT for depression has an excellent empirical support. The authors discuss other relevant aspects, such as the rapid expansion of controlled trials for other disorders (e.g., panic disorder, agoraphobia, social phobia); the use of other treatments than CBT (e.g., physical activity or psychodynamic Internet therapy); the possibility of testing transdiagnostic and tailored interventions; and the role of the support provided to the patients during ICBT. In another work also centred on the use of internet, Cujipers and Riper offer an overview of the research on psychotherapeutic internet interventions and discuss important issues associated with these advances, such as the effectiveness of Internet-based treatments for depression; whether Internet-based and other guided self-help interventions are as effective as face-to-face therapies, or whether they should be delivered only for mild to moderate problems; and the role and 
amount of professional support provided to the patients during internet-based treatments. The authors also discuss the implementation of these interventions both inside the public and private mental health systems. They defend the convenience of implementing innovative intervention strategies to help resolve the outstanding problems in the field of mental health, from the routine integration of these internet-based interventions in primary care and specialized mental health care, to the development of specific interventions for relapse prevention and maintenance of the achievements acquired during therapy. The authors conclude that such interventions can help alleviate the burden of mental health problems, both in industrialized countries and in emerging countries or third world countries.

The application of ICTs in psychological interventions designed for children and adolescents is the focus of two articles in this issue. Bornas, Llabrés, Balle, Torre-Luque, and Fiol-Veny explore the possibilities of using a secure social network for gathering more accurate data on anxious symptomatology in adolescents. Two studies are presented: Study 1 describes the structure and functioning of the XS2 secure social network is described, alongside results of the participants' access and use of the network; Study 2 presents the results of variations in the participants' daily emotional state and their use of maladaptive emotion regulation strategies during an exam period, as well as the influence of risk factors on these strategies. They discuss both the benefits that such a network can bring to the study of the evolution of anxiety problems in adolescents and the challenges of contacting and motivating the participants to use the network. Fleming, Cheek, Merry, Thabrew, Bridgman, Stasiak, Shepherd, Perry, and Hetrick explore the potential contribution of serious games in mental health interventions. They focus on interventions based on serious gaming designed to aid in the treatment for depression. The authors discuss the advantages and benefits these interventions can have for children, adolescents, and young people with depression, and then highlight the shortcomings of the research conducted in this field thus far. The results of this review indicate that serious games might be useful strategies for the treatment of depression in these populations, but at the moment the literature in this field is limited.

Given the remarkable development that has occurred in this area of research, it is impossible to reflect the current situation in its entirety; nevertheless, this special issue outlines the possibilities offered by the ICTs for Clinical Psychology. We hope these examples serve to encourage mental health professionals to include these new tools based on ICTs in their everyday clinical practice. Likewise, we also hope that these examples will help researchers interested in advancing the field by exploring the potential that ICTs have for improving and disseminating evidence-based psychological interventions.

\section{REFERENCIAS /REFERENCES]}

Andersson, G. (2009). Using the Internet to provide cognitive behaviour therapy, Behaviour Research and Therapy, 47, 175-180.

Andrews, G., Cuijpers, P., Craske, M.G., McEvoy, P., \& Titov, N. (2010). Computer therapy for the anxiety and depressive disorders is effective, acceptable and practical health care: A Meta-Analysis. PLoS ONE, 5: e13196. doi:10.1371/journal.pone.0013196

Clough, B.A., \& Casey, L.M. (2011). Technological adjuncts to enhance current psychotherapy practices: A review. Clinical Psychology Review, 31, 279-292.

Botella, C., García-Palacios, A., Baños, R.M., \& Quero, S. (2009). Cybertherapy: Advantages, limitations, and ethical issues. PsychNology Journal, 7, 77-100.

Botella, C., García-Palacios'A., Quero, S., Baños, R. M., y Bretón-López, J.M. (2006). Realidad virtual y tratamientos psicológicos: Una revisión. Behavioral Psychology-Psicología Conductual, 14, 491-510.

Cuijpers, P., Donker, T., Johansson, R., Mohr, D.C., Straten, A., \& van Andersson, G. (2011). Self-guided psychological treatment for depressive symptoms: A meta-analysis. PLoS ONE, 6: e21274.

Cuijpers, P., Donker, T., van Straten, A., Li, J., \& Andersson, G. (2010). Is guided self-help as effective as face-to-face psychotherapy for depression and anxiety disorders? A systematic review and metaanalysis of comparative outcome studies. Psychological Medicine, 40, 1943-1957.

David, D., Matu, S., \& David, O.A. (2013). New Directions in Virtual Reality-Based Therapy for Anxiety Disorders. International Journal of Cognitive Therapy, 6, 114137. 
McCann, R.A., Armstrong, C.M., Skopp, N.A., EdwardsStewart, A., Smolenski, D.J., June, J.D., MetzgerAbamukong, M., \& Reger, G.M. (2014). Virtual reality exposure therapy for the treatment of anxiety disorders: An evaluation of research quality. Journal of Anxiety Disorders, 28, 625-631.

Miller, G. (2012). The Smartphone Psychology Manifesto, Perspectives on Psychological Science, 7, 221-237.

Newman, M.G., Szkodny, L., Llera, S., \& Przeworski, A. (2011). A review of technology-assisted self-help and minimal contact therapies for anxiety and depression: Is human contact necessary for therapeutic efficacy? Clinical Psychology Review, 31, 89-103

Opris, D., Pintea, S., García-Palacios, A., Botella, C., Szamosközi, S., \& David, D. (2012). Virtual reality exposure therapy in anxiety disorders: A quantitative meta-analysis. Depression and Anxiety, 29, 85-93.
Powers, M. B., \& Emmelkamp, P. (2008). Virtual reality exposure therapy for anxiety disorders: A meta-analysis. Journal of Anxiety Disorders, 22, 561-569.

Richards, D., \& Richardson, T. (2012). Computer-based psychological treatments for depression: A systematic review and meta-analysis. Clinical Psychology Review, 332, 329-342. doi: 10.1016/j.cpr.2012.02.004.

Spek, V., Cuijpers, P., Nyklicek, I., Riper, H., Keyzer, J., \& Pop, V. (2007). Internet based cognitive behaviour therapy for symptoms of depression and anxiety: A meta-analysis. Psychological Medicine, 37, 319-328.

Turner, W., y Casey, L.M. (2014). Outcomes associated with Virtual Reality in Psychological Interventions: Where Are We Now? Clinical Psychology Review, 34, 634-644. 